\title{
A study in dispossession: the political ecology of phosphate in Tunisia
}

\author{
Mathieu Rousselin ${ }^{1}$ \\ Independent Researcher, Dortmund, Germany
}

\begin{abstract}
This article seeks to evidence the social, environmental and political repercussions of phosphate extraction and transformation on two peripheral Tunisian cities (Gabes and Gafsa). After positing the difference between class environmentalism and political ecology, it addresses the harmful effects of phosphate transformation on the world's last coastal oasis and on various cities of the Gulf of Gabes. It then sheds light on the gross social, environmental and health inequalities brought about by phosphate extraction in the mining region of Gafsa. The confiscatory practices of the phosphate industry are subsequently linked with global production and distribution chains at the international level as well as with centralized and authoritarian forms of government at the national and local level. Dispossessed local communities have few alternatives other than violent protest movements and emigration towards urban centers of wealth. Using the recent experience in self-government in the Jemna palm grove, the article ends with a reflection on the possible forms of subaltern resistance to transnational extractivism and highlights the ambiguous role of the new "democratic state" as a power structure reproducing patterns of domination and repression inherited from the colonial period and cemented under the dictatorship of Ben Ali.
\end{abstract}

Keywords: political ecology, transnational extractivism, phosphate, Tunisia.

\section{Résumé}

Cet article s'efforce de mettre en évidence les répercussions sociales, environnementales et politiques de l'industrie d'extraction et de transformation du phosphate sur deux villes de la périphérie tunisienne (Gabès et Gafsa). Après avoir exposé la différence entre l'environnementalisme de classe et l'écologie politique, cet article analyse les effets délétères de la transformation du phosphate sur la dernière oasis littorale du monde ainsi que sur plusieurs villes du Golfe de Gabès. L'article met ensuite en lumière les profondes inégalités en matière sociale, environnementale et de santé causées par l'extraction du phosphate dans le bassin minier de Gafsa. Les pratiques confiscatoires de l'industrie du phosphate sont ensuite mises en relation avec les chaînes globales de production et de distribution au niveau international ainsi qu'avec les formes de gouvernement centralisées et autoritaires au niveau national et local. Les communautés locales dépossédées ont peu d'autres choix les mouvements de protestation violents ou l'exil vers les centres de richesse urbains. À partir de l'expérience d'autogestion de la palmeraie de Jemna, l'article s'achève par une réflexion sur les possibilités de résistance subalterne à l'extractivisme transnational et souligne le rôle ambigu du nouvel «État démocratique » comme structure de pouvoir reproduisant les mécanismes de domination et de répression hérités de l'époque coloniale et consolidés sous la dictature de Ben Ali.

Mots-clés: Écologie politique, extractivisme transnational, phosphate, Tunisie.

\section{Resumen}

Este artículo pretende evidenciar las repercusiones sociales, ambientales y políticas de la industria de extración y transformación del fosfato para dos cuidades tunecinas periféricas (Gabes y Gafsa). Después de plantear la diferencia entre el ambientalismo de clase y la ecología política, este artículo aborda las consecuencias nocivas de la transformación del fosfato sobre la última oasis costera del mundo y sobre varias ciudades del golfo de Gabes. Luego se echa luz sobre las desigualdades sociales, ambientales y en

\footnotetext{
${ }^{1}$ Dr. Mathieu Rousselin, Jagdhausstrasse 5, 44225 Dortmund, Germany. Email rousselin.mathieu"at" gmail.com. http://independent.academia.edu/MathieuRousselin. He has a Ph.D. in international relations and political economy from the University of St. Gallen, Switzerland. His research interests include political ecology, social movement theory, Marxism and critical theory as well as the study of transformation processes with a particular focus on Tunisia. His research has been published in New Media and Society, Euxeinos, the European Foreign Affairs Review, Global Dialogues, Multitudes, the Journal of Environmental Policy and Planning, WeltTrends, Critique and Science and Society. He is also the author of two books: Widerstand (Westfälisches Dampfboot 2014) and Can asymmetrical cooperation be legitimised? (Institut für Auslandsbeziehungen 2017). Many thanks to two reviewers.
} 
salud que resultan de la extración del fosfato en la cuenca minera de Gafsa. Subsecuentemente se conectan las prácticas confiscatorias de la industria del fosfato con cadenas mundiales de producción y distribución en el ámbito internacional así como también con formas de gobierno centralizadoras y autoritarias en el ámbito nacional y local. Comunidades locales desposeídas tienen muy pocas alternativas aparte de movimientos violentos de protesta o de la inmigración hacia centros urbanos de riqueza. A partir de la experiencia de autogestión en el palmar de Jemna se acaba ese artículo con una refleción sobre las posibilidades de resistancia subalterna contra el extractivismo transnacional y pone de evidencia el papel ambiguo del nuevo "estado democrático" come estructura de poder reproduciendo patrones de dominación y represión heredados del período colonial y consolidados bajo la dictadura de Ben Ali.

Palabras clave: Ecología política, extractivismo transnational, Fosfato, Túnez.

\section{Introduction}

I cannot over-emphasize the importance of phosphorus not only to agriculture and soil conservation, but also the physical health and economic security of the people of the nation. [...] Therefore, the question of continuous and adequate supplies of phosphate rock directly concerns the national welfare.

Franklin Delano Roosevelt, Message to Congress on Phosphates for Soil Fertility. May 20, 1938 http://www.presidency.ucsb.edu/ws/?pid=15643

Substitutes: There are no substitutes for phosphorus in agriculture.

U.S. Geological Survey, Mineral Commodity Summaries, January 2009 - available at: https://minerals.usgs.gov/minerals/pubs/commodity/phosphate_rock/mcs-2009-phosp.pdf

Tunisia's President Beji Caid Essebsi on Wednesday ordered the army to protect phosphate, gas and oil production facilities after protests aimed at disrupting output broke out in the south of the country. It is the first time troops in Tunisia will be deployed to protect industrial installations vital to Tunisia's economy. [...] For several weeks, about 1,000 protesters in Tatouine province, where Italy's ENI and Austria's OMV have gas operations, have been demanding jobs and a share in revenue from the area's natural resources. Protests have also broken out in another southern province, Kebili, and on Wednesday police fired tear gas to break up rioting [...] Protests that have hit the phosphate sector in past years cost the country more than $\$ 2$ billion, according to officials.

Reuters, 'Tunisian president orders army to protect oil and gasfields', 10/05/2017, available at: http://www.reuters.com/article/us-tunisia-economy-idUSKBN1861DN

As these quotes suggest, phosphate is a rare and valuable commodity. Organic farming aside ${ }^{2}$, modern agriculture is crucially dependent on phosphate fertilizers to boost crop growth and replenish soils after harvest. With a global population expected at 9.7 billion in 2050 (United Nations 2015), the use of phosphate fertilizers to increase agricultural outputs appears indispensable to many. ${ }^{3}$ Fueled by developing

\footnotetext{
${ }^{2}$ It is estimated that 60 million hectares of agricultural land worldwide are organic, representing a mere $1 \%$ of the worldwide agricultural land (Willer and Lernoud 2017). With a global market of 75 billion euros (US\$101bn) and a market share of around 8\%, organic agriculture is a rapidly expanding sector whose growth reached 25\% in 2016 (ibid.) It should be noted that organic farming is an imperfect proxy for the total amount of agricultural land cultivated without phosphate fertilizers, since it does not factor in subsistence agriculture for which commercial fertilizers are too expensive. At the same time, even subsistence farmers may use naturally occurring calcium phosphates (as present for instance in lime) to boost agricultural output, so that determining the exact amount of land dedicated to phosphate-free farming is particularly challenging.

${ }^{3}$ The issue of comparative yields between organic and conventional farming, though crucial due to its linkage with global food security, cannot be addressed at the level of depth it deserves in this article. Suffice it to say that studies on the issue have led to contradictory and evolving results. Ten years ago, the FAO concluded that "data and models regarding the productivity of organic as opposed to conventional farming show that the potential of organic agriculture is far from large enough to feed the world" (United Nations 2007). At the same time, studies have shown that the use
} 
economies, the world demand for phosphate is steadily increasing and generates very substantial revenues for mining companies in producing countries (see Figures 1 and 2). The most important phosphate reserves are located in China, the US and Morocco: yet, China imposes a prohibitive tariff on phosphate exports in order to secure its own domestic supply; despite important reserves, the US remains the world's largest importer of phosphate in order to slow down the depletion of its own national resources (estimated at 25 years); and Morocco is a geopolitically sensitive trade partner since phosphate rocks are located in Western Sahara, a region Morocco occupies in violation of international law (Cordell 2008).

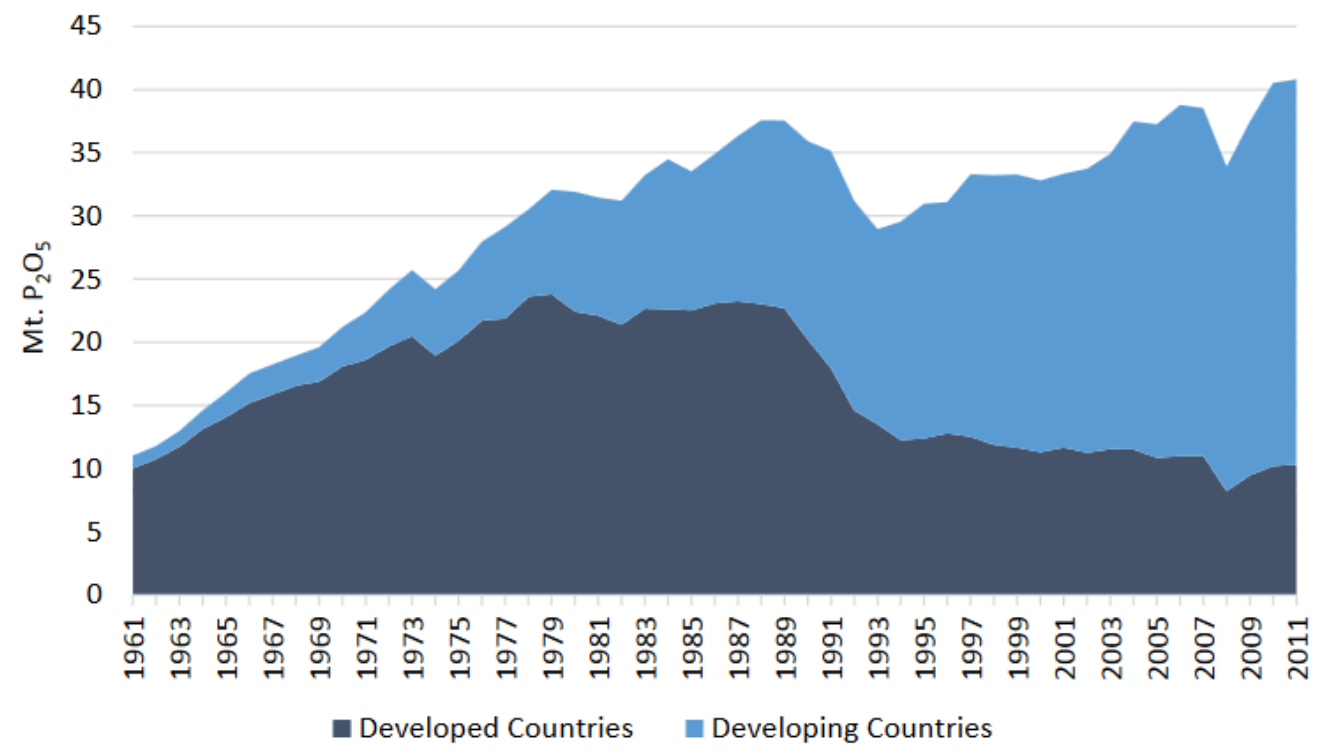

Figure 1: Phosphate fertilizer consumption in developed and developing countries. Source: Heckenmüller et al. 2014: 5.

Under such circumstances, the phosphate-rich regions of the Tunisian Interior such as the governorate of Gafsa where the Compagnie des Phosphates de Gafsa has its headquarters ought to be doing very well since they are literally sitting on gold. By the same token, some of that wealth ought to remain along the distribution chain in those regions that are associated with the transformation and shipping of the valuable mineral, for instance in the governorate of Gabes, where the headquarters of the Groupe Chimique Tunisien are located. But this is not the case. Quite the contrary: compared with the capital city of Tunis and the Northern coastline, both Gafsa and Gabes governorates are underdeveloped regions and cities that are historical hotbeds of the phosphate industry - such as Moulares, Redeyef, Medlaoui, Mdhilla for extraction and Sfax, Gabes, Skhira, Ghannouch for transformation - are statistically among the poorest of the country (Hamdène 2016), combining high levels of unemployment and of environmental degradation with insufficient provision of public services and infrastructure.

Drawing upon political ecology, this article sets itself two main tasks: first, to investigate the set of historical and material conditions that led to the current situation of wealth confiscation or "accumulation by dispossession" (Harvey 2004); and, second, to provide evidence for the social, environmental and political consequences of phosphate extraction and transformation on two peripheral Tunisian cities (Gabes and Gafsa). In addition to relevant scientific literature, the evidence used consists of discourses of environmental mobilization produced by Tunisian activists and circulated via alternative media channels (documentary films and blogging platforms). The second section posits the difference between class environmentalism (a purportedly apolitical framework advocating targeted environmental protection

of phosphate fertilizers is subject to decreasing returns to scale as far as crop yields are concerned (Römer 2009). In addition, a 2012 study published in Nature showed that "yield differences are highly contextual, depending on system and site characteristics, and range from $5 \%$ [...] to 34\% [...]. Under certain conditions - that is, with good management practices, particular crop types and growing conditions_-organic systems can thus nearly match conventional yields." (Seufert et al. 2012) 
measures geared towards technical and managerial problem-solving with little consideration for the effect of these measures on social and environmental inequalities), and political ecology (a conceptual and normative approach drawing from critical scholarship to emphasize the embeddedness of environmental issues in global networks of production and exchange as well as in political and social practices of hegemony and resistance). After detailing the methodology, the fourth section addresses the environmental, ecological and health consequences of phosphate transformation on the world's last coastal oasis as well as on various cities of the Gulf of Gabes. Section five documents the social, environmental and political inequalities brought about by phosphate extraction in the mining region of Gafsa and subsequently links extractivism with centralized and authoritarian practices, against which local populations have little or no alternative other than violent protest movements and emigration towards urban centers of wealth. Using the recent example of the self-management experience in the Jemna palm grove, the sixth section reflects on the possible forms of subaltern resistance to transnational extractivism, and highlights the ambiguous role of the new "democratic state" as a power structure reproducing domination patterns inherited from the colonial period.

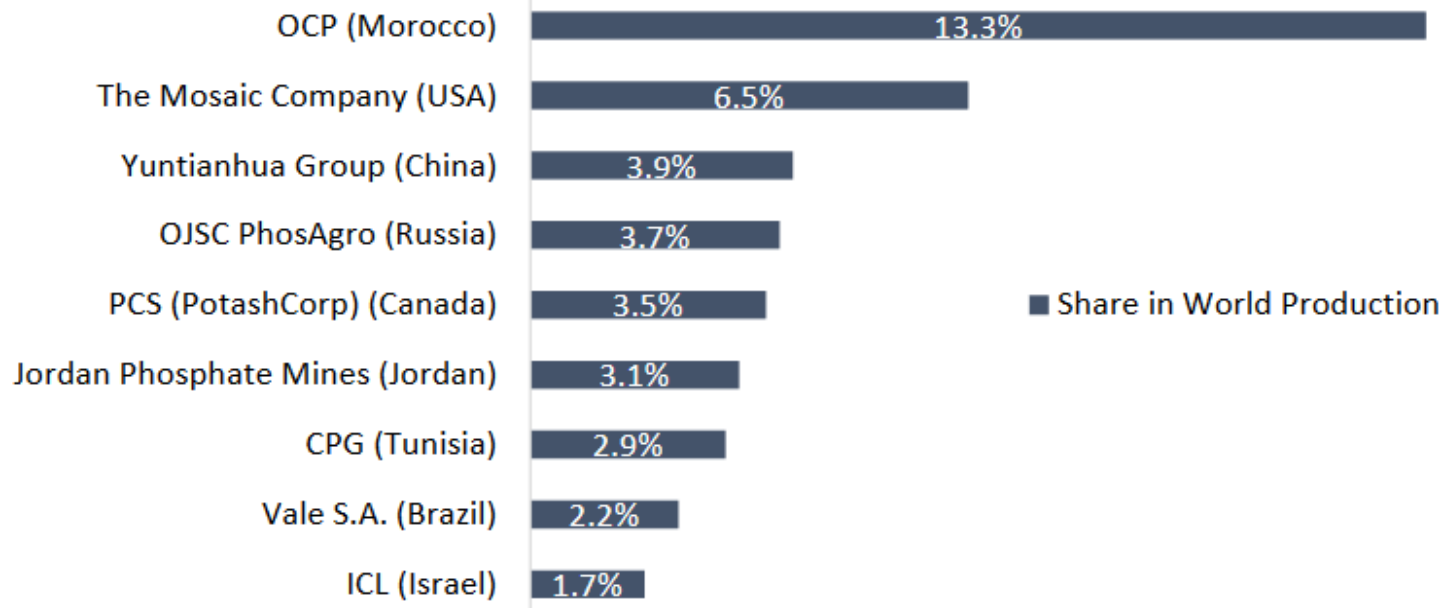

Figure 2: World's largest phosphate rock producers as of 2012. Source: Heckenmüller et al. 2014: 8 .

\section{Political ecology versus class environmentalism}

During a trip to Tunis in 2015, a good friend sententiously announced to me that "the revolution will be successful when the new democratic state is able to take care of its litter (poubelles) as efficiently as Ben Ali did." For a European expat working in the classy neighborhood of Les Berges du Lac and living in the almost equally posh quarter of La Marsa, le problème des poubelles ("the litter problem") was indeed the most pressing environmental issue he could think of - and certainly the one he was most directly confronted with. To be fair, this perception was by no means circumscribed to the circle of diplomats, foreign multinational executives and employees of international organizations. In conversations with political actors, university professors and local businessmen - many of whom were living in the same privileged districts as the expat community - as well as in the daily small talks in cafés of the Avenue Bourguiba or in shops of Le Bardo, le problème des poubelles was a "popular" topic of conversation. There was almost universal agreement on the proposition that the state ought to be doing more to "educate people" not to throw trash in the open. This hygienist line of argumentation combined with various economic considerations on the price of uncleanliness (usually understood in terms of the negative impact on the tourism industry), was also developed often in the francophone newspapers La Presse and Le Temps. This contributed to pitch and frame le problème des poubelles as a major issue of public concern, prompting various governmental awareness-raising campaigns ${ }^{4}$ and eventually leading to important but largely

\footnotetext{
${ }^{4}$ National property campaign in May/April 2014 and national property programme launched in February 2015. See "300,000 tonnes de déchets dans les rues, le gouvernement lance une campagne nationale de propreté" (Huff Post
} 
symbolic - because largely unapplied - decisions such as the criminalization of illegal waste dumping (in theory up to 90 days imprisonment and/or 1,000 dinar (US\$406) fines, in a country where the average monthly pay reaches 800 dinars (US\$325) ${ }^{5}$, or the recent ban on plastic bags in supermarkets. ${ }^{6}$

Sure enough, mounting piles of ill-smelling waste bags ripped open by stray cats, leaving food leftovers to rot under the blazing sun are a most unpleasing sight. They also constitute a very serious threat to public health and violate the dignity of all humans condemned to living in their midst. Thus, there is little doubt that the litter problem is a major inconvenience to all Tunisian citizens irrespective of their social class. Yet, as polemic and controversial as this may sound, dirty streets are certainly not the most critical problem in post-revolutionary Tunisia from an ecological perspective - and, for that matter, neither is the institution of a well-functioning public service for the collection and disposal of household refuse the most urgent, let alone the most important, measure to be adopted for the purpose of environmental protection. As convincingly argued by Habib Ayeb (2015 and 2016), a number of much more worrisome ongoing developments are met with the almost universal indifference of those same voices who so vigorously clamor for street-cleaning and sweeping services. So is the extreme pollution of Lake Sijoumi (South-West of Tunis), caused by the lack of sufficient waste-water treatment facilities, resulting in the destruction of the fragile ecosystem and numerous safety and health hazards for mostly poor local populations. Another example of such selective indignation is the loss of biodiversity induced by mass tourism in regions such as Djerba, where vulnerable coastal areas have been disfigured by hotel resorts and powerfully motorized quad bikes used for guided tours.

Framed in liberal-paternalistic terms ("it is the individual's responsibility not to throw litter in the street and this responsibility must be conveyed to the uninformed/uneducated masses by means of pedagogical campaigns"), the "litter problem" reflects the preoccupation of a social group that was not used to considering garbage as part of its geography. But now it is confronted, physically and visually, with ugliness and uncleanliness. Echoing previous research on the social and political mobilization strategies of the upper class to keep certain quarters green, clean and proper (Pinçon-Charlot and Pinçon 2007, 2009), the media frenzy about the "litter problem" is thus the expression of a sociological elite's capacity to protect and embellish its territories - in other words, the expression of a form of "class environmentalism."

Against class environmentalism, this article puts forward political ecology as a critical conceptual framework and as a radical normative project. From a conceptual perspective, political ecology draws upon (international) political economy to contextualize and historically situate the set of socio-political factors that accounts for environmental developments - such as pollution, resource degradation or biodiversity loss - that are usually attributed to the inevitable play of natural forces or environmental hazards. In his pioneering work on soil erosion and land degradation in developing countries, Piers Blaikie (1985 and Blaikie and Brookfield 1987) shows for instance that standard explanations, such as the inappropriate use of technologies, a lack of technical knowledge, land mismanagement or regional overpopulation cannot account for environmental degradation as long - as they do not factor in the effects of "the politicaleconomic context in which land-users find themselves" (Blaikie 1985: 32). It is this political-economic context, from the international to the local level, which explains why intensive and abrasive land use practices are systemically favored over others, more conservation-friendly. In a similar vein, Michael Watts argues that the causation between drought and famine in Nigeria is not of a direct and automatic nature but is rather "mediated through the political and economic architecture of the social system" (Watts 1983: 104). In particular, the inclusion of millions of African peasants in global circuits of production by the colonial powers resulted in all sorts of regulatory bans and market incentives that deeply affected time-tested farming practices, diminishing the resilience of local communities in the face of climatic variability by increasing their dependence on a small number of economically viable but climate-sensitive crops. Blaikie and Watts' works thus place relationships of production and notions of power - mostly understood in terms of access to resources and control over their distribution - at the center of the analytical apparatus. Analytically, most political ecologists rely on a critical reading of Marx. They retain a standard Marxist toolkit (the primate of exchange value, the notions of surplus-labor or value-creating labor and the intuition of a form of negative solidarity between Labor and Nature in the face of Capital's ineluctable tendency to

Maghreb / Tunisie later HPM/T, 7/4/2014); "Tunisie - accumulation des déchets: saviez-vous qu'il y avait un "programme national de propreté"?" (HPM/T 27/4/2015).

${ }^{5}$ See "L'environnement, première victime de la révolution?" (HPM/T 5/4/2016).

${ }^{6}$ Or rather: at supermarket checkouts, since plastic bags are still lawfully in use at the grocery department of those same supermarkets! See "La Tunisie interdit les sacs plastique dans les supermarchés" (HPM/T 1/3/2017). 
form 'a system of universal exploitation of natural and human qualities'). But they strip Marxism from its nineteenth century mystique of production and from its belief in 'the great civilizing influence of Capital' (Bensaïd 1993; Harribey 2001; Löwy 2003). The important critical task of the political ecologist is then to understand the global explanatory chain of material (political-economic) conditions that led to certain environmental problems to emerge (such as pollution, desertification or deforestation), or certain conflicts with alleged environmental roots to prosper (overpopulation, climate refugees). ${ }^{7}$

Yet, political ecology - particularly in the Francophone scientific discourse - also has an unmistakable normative ambition. Building upon the work of Nicholas Georgescu-Roegen and Jacques Ellul, philosophers and economists such as François Partant (1982) convincingly evidenced the impossibility of an infinite growth in production and consumption in a world of finite resources - a critique that has was subsequently applied to the more modern concepts of "sustainable development" (Mathias 2009) or "green capitalism" (Tanuro 2012). Another stream of researchers went on to emphasize the strong correlation between social and environmental inequalities (Kempf 2007; Keucheyan 2014). On this basis, prominent academics such as André Gorz (2008) or Serge Latouche (2006) developed the concept of degrowth, calling for a voluntary reduction in production and consumption as a means of countering resource depletion and as a necessary step towards more environmental and social justice. ${ }^{8}$ Some political ecologists close to the global justice movement put forward the doctrine of eco-socialism (Löwy 2011) and endorsed a number of alternative policies in a wide array of sectors: community-supported agriculture, slow cities and ecovillages (Hapagès and Latouche 2012); universal and unconditional basic income (Gorz 1997); work-sharing models and global reduction in working hours (Lipietz 1996); but also greater public transparency on party-funding and the role of lobbies, new possibilities for direct democratic control over elected representatives (a recall referendum) or the institutional recognition of new forms of political participation such as "none of the above" voting, or local consultations on projects of environmental interest (Collectif 2012).

\section{Methodology}

In order to investigate the confiscatory workings of the phosphate industry in Tunisia, the article analyzes discourses of environmental mobilization produced by researchers, filmmakers and investigative journalists whose work can be seen both as inspired by and contributing to political ecology. Since this research was conducted as a desk study without fieldwork in Gabes or Gafsa, it does not provide interview data on the sociological profiles or ideological motivations of participants in social movements. Rather, the material consists of non-commissioned documentary films circulated via alternative distribution channels as well as of articles published in the collective blogging platform Nawaat. Though the material can to a large extent be called "independent" - in particular from power structures - the discourses analyzed are by no means "neutral." Indeed, they were produced by Tunisian activists committed to the global justice movement and engaged in a socio-political struggle with the triple aim of pointing to state of affairs deemed problematic, of providing a certain reading of past events accounting for the current state of affairs and of legitimizing certain courses of action in response, hence gathering support for certain political solutions.

The fact that these discourses have to be apprehended while keeping in mind the positionality of their authors and the specificities of their format should not be equaled to a principled disqualification from use in scientific inquiry. First, the same basic rules of caution apply to all manner of discourses, from government reports to scientific publications. Second, though the work of activists, the material selected is able to withstand the critical scrutiny of the scientist. Known for its unusually long and meticulously documented analyses, the collective blogging platform Nawaat is for instance one of the most reliable sources of independent, high quality information for researchers interested in Tunisian current affairs. Begun in 2004 to bypass the censorship of the ben Ali regime over the media, the platform has grown to become a model of investigative journalism, earning numerous national and international awards and playing a key role in unveiling the extent of corruption both under the ben Ali regime and after its downfall (TuniLeaks and NawaatLeaks).

Similarly, it is worth taking a few moments to reflect on the use of documentary films within social scientific research. Documentary films oftentimes rely on investigative methods that are typical of

\footnotetext{
${ }^{7}$ For an overview of the relationship between political ecology and other critical theories, see Robbins 2012: 49-81.

${ }^{8}$ On the same topic, see the special section on "Degrowth, culture and power" edited by Lisa L. Gezon and Susan Paulson in the Journal of Political Ecology 24: 425-666.
} 
qualitative research: use of archives, analysis of textual or audio-visual material, various interview techniques not to mention a wide spectrum of participant observation techniques when filmmaker and camera crew physically take part in the events (meetings, demonstrations, strikes, etc.) that they seek to depict. This approach is epitomized in the first documentary film (Gabès labess) which is directed by a professional scientist and seasoned qualitative researcher (Habib Ayeb, Professor of Geography at the University of Paris-VIII). Yet, social researchers should by no means limit themselves to investigative, factbased documentary films, on the grounds that these films are more objective or truthful - because such films are rarely the most powerful. Documentary films that feature more stylized camera work as well as subjective, perhaps even fictional elements may also be used in social scientific research to great benefit. Echoing philosophical and epistemological debates on the possibility of scientific objectivity and of valuefree research, German filmmaker Werner Herzog (2007) for instance convincingly debunked the myth of Direct Cinema or cinema vérité whereby the objective truth of facts may be conveyed by unobtrusive filming techniques (the fly on the wall) that neither "distorts" situations nor "interferes" with characters. Taking the example of the telephone directory - a factually impeccable and yet most tiresome and incomprehensible read - Herzog contends that a purely factual approach aiming at the restitution of all relevant information available does not allow the production and diffusion of meaningful messages. To this "accountant truth", Herzog opposes a deeper form of truth (that he calls "ecstatic truth") which emerges out of the arrangement, ordering and rendering of the factual basis by the filmmaker. The second film selected in this article (Cursed be the phosphate) is an example of such an approach: recitations of Arabic poetry and skillfully dramatized interviews are used to assist, but also to direct, to suggest a reading and hence to manipulate the viewer into processing the information in a particular way. Just as with any other material, the viewer then has to decide for herself whether she deems the attempt at manipulation to be legitimate.

\section{Gabes: death of an oasis}

On the face of it, Zine el-Abidine Ben Ali was a convinced environmentalist. Under his authoritarian rule between 1987 and 2011, Tunisia established a National Agency for the Protection of the Environment ${ }^{9}$, ratified a number of international conventions on matters of environmental protection ${ }^{10}$, inaugurated a boulevard or avenue de l'environnement in virtually every large city in the country ${ }^{11}$, adhered to the European emission standards for motor vehicles ${ }^{12}$, created 8 national parks and 16 national reserves, diligently undertook "climate change impact studies"13 - and made use of UNDP funding to issue information and awareness bulletins with cranky titles and pictures of Ben Ali planting trees. ${ }^{14}$ Much of it was for show (or for foreign donors): waste discharge and industrial emissions were not systematically monitored, patent violations of basic anti-pollution laws were not sanctioned and environmental cleanup programs were restricted to city centers and tourist areas (Goldstein 2014).

This grand-sounding approach to environmental protection survived the downfall of the green dictator: in the new constitutional text ${ }^{15}$, environmental rights occupy a truly remarkable and almost unique

\footnotetext{
9 The Agence Nationale de Protection de l'Environnement was created by Law No. 88-91 of 2 August 1988.

${ }^{10}$ During the Earth Summit in Rio (1992), Tunisia signed the United Nations Framework Convention on Climate Change (UNFCCC), which it ratified a year later. Under ben Ali, Tunisia also became a party to the Kyoto Protocol as early as 2002, three years before it entered into force.

${ }^{11}$ Béja, Hammamet, Nabeul, Siliana, Cathage, Sfax - and Gabes.

${ }^{12}$ In January 2008, Tunisia became the first North-African country to join the "Agreement concerning the adoption of uniform technical prescriptions for wheeled vehicles, equipment and parts which can be fitted and/or be used on wheeled vehicles and the conditions for reciprocal recognition of approvals granted on the basis of these prescriptions" (E/ECE/TRANS/505/Rev.2). Contracting parties to this agreement adopt common regulations governing type approval for vehicles and components, including engine fuel requirements and pollutant emissions according to R83.

${ }^{13}$ For instance an impact study on the effects of climate change on agriculture and ecosystems ("Étude sur l'adaptation de l'agriculture et des écosystèmes aux changements climatiques") or on the effects of the rise in sea levels on marine ecosystems and on the economy of coastal regions ("Étude sur les impacts de l'élévation du niveau de la mer sur les écosystèmes marins et sur l'économie des régions littorales exposées à ce risqué").

14 "For a global alliance through international solidarity to protect life on earth" (Pour une alliance globale à travers une solidarité internationale pour la protection de la vie sur terre). This masterpiece of governmental propaganda is still available online: http://www.environnement.gov.tn/fileadmin/medias/pdfs/etat_env/rapport_enviro_franc.pdf

15 An English translation of the 2014 Tunisian Constitution can be found here: https://www.constituteproject.org/constitution/Tunisia_2014.pdf
} 
place that ought to give Tunisian courts the means to adopt pioneering environmental jurisprudence. ${ }^{16}$ In the Preamble, the Tunisian People declares "In the Name of God, the Merciful, the Compassionate" its awareness of "the necessity of contributing to the preservation of a healthy environment that guarantees the sustainability of our natural resources." The protection of the environment is then specifically addressed in two further articles: article 44 guarantees all Tunisian citizens "the right to water" and affirms that "the conservation and rational use of water is a duty of the state and of society"; article 45 says that the state "guarantees the right to a healthy and balanced environment and the right to participate in the protection of the climate" and, to this end, "shall provide the necessary means to eradicate pollution of the environment." Yet, anybody who recalls the Soviet Constitution of 1977 knows that rights and protections that are magnanimously granted at the macro-level do not necessarily translate into everyday practices at the microlevel. The region of Gabes provides an edifying illustration of this discrepancy.

\section{Phosphate transformation in Gabes}

Situated on the Mediterranean coast 400 kilometers away from Tunis, the Gulf of Gabes is nestled between mountains, the Mediterranean coast, a seaside oasis and the desert (Figure 3). An important bird sanctuary, the Gulf of Gabes is also the only part of the Mediterranean with a substantial tide (up to 2 meters) that uncovers extensive sandbanks at low water. The gentle slopes of the continental shelf combined with the lush seagrass bed and the abundant plankton and nutrients used to ensure a highly diverse marine biomass, including numerous fish species that were a source of livelihood for a once-flourishing fishing industry. But the city's greatest pride is undoubtedly its seaside oasis. With its rich biological and cultural diversity as well as its complex system of irrigation ${ }^{17}$, the oasis used to extend over 1,000 hectares up until the 1970s. The documentary film Gabès labess (2014) traces the reasons that led to the demise of this unique site once nicknamed "the paradise of the world" and uses this example to question productivism as a mode of development in more general terms. Indeed, Gabes is an almost ideal-typical case of the contemporary confiscatory practices of extraction industries in the global South: a region experiencing high levels of poverty and unemployment (World Bank 2014: 283) hosted a lucrative but polluting industry in the confidence that it would generate export revenues and boost local development. And yet, local job creation remains limited and is even offset by the destruction of traditional economic sectors such as farming or fishing brought about by pollution, while local populations and ecosystems are plagued by environmental and health hazards.

With the construction of a phosphate-refining plant in 1972, Gabes became home to an industrial chemical complex that rapidly grew to include petrochemical plants and oil refineries. The promise of attractive positions in state companies led to population growth, which needed to be accommodated via the building of thousands of new homes. Fueled by the construction and chemical industries, the urban area expanded into the oasis, eating up $80 \%$ of its former surface, now estimated at around 200 hectares. ${ }^{18}$ As highlighted by Carpentier and Gana (2015) and Ayeb (2012), the consolidation of an agro-business sector largely oriented towards the export of products for which there is a strong international demand (such as Deglet Nour dates) led to the increased marginalization and dispossession of entire segments of the traditional peasantry practicing more diversified forms of oasis agriculture in small family farms. In addition to spatial competition for arable land, (agro-)industrial activities also placed a high burden on natural sources of water. Guillermou (2011) showed that, despite claiming the monopoly over the exploitation of deep water tables, the Tunisian state did tolerate the practice of "illegal drilling" by the industry, to the extent that it enabled restructuring and modernizing oasis agriculture as well as boosting date production for export. Here again, the tolerated practice of illegal drilling further reinforced the marginalization of small farmers as it primarily benefited a handful of larger producers with close ties to investors and state officials. In addition, small farmers were also forced to resort to pumped irrigation and must now pay electricity bills for pumped water that used to flow for free. As a result of these processes,

\footnotetext{
${ }^{16}$ So far, only two further nations worldwide have inscribed similarly ambitious provisions on climate protection in their fundamental law: Ecuador and the Dominican Republic (Fadhel and Osman 2014).

17 More information about this fantastic site can be found on the UNESCO website: http://whc.unesco.org/fr/listesindicatives/5386/

${ }^{18}$ These are numbers provided by geographer Irène Carpentier for the traditional oasis of Chenini Gabes - see: "Tunisian seaside oasis of Gabes under threat from construction", 08 April 2014, available at: http://www.itnsource.com/en/shotlist/RTV/2014/04/08/RTV080414072/. In Gabès Labess, Habib Ayeb mentions a decline in agricultural land from 1,250 to 650 hectares for the entire oasis.
} 
aquifers in Tunisian oases are in a chronic state of overexploitation ${ }^{19}$, a situation also found in Gabes, where two of the largest groundwater bodies (Gabes-South table and the El Hamma-Chenchou table) are intensely exploited. ${ }^{20}$ Historical hydrological data from the Tunisian Ministry of Environment (see Figure 4) confirms that the 400 natural springs (artesian wells) that used to irrigate the oasis have all been drilled to exhaustion, so much that researchers even question the very use of the term "oasis" when referring to the irrigated agrarian landscape of Chenini Gabes (Abdedaiem and Veyrac-ben Ahmed 2015).

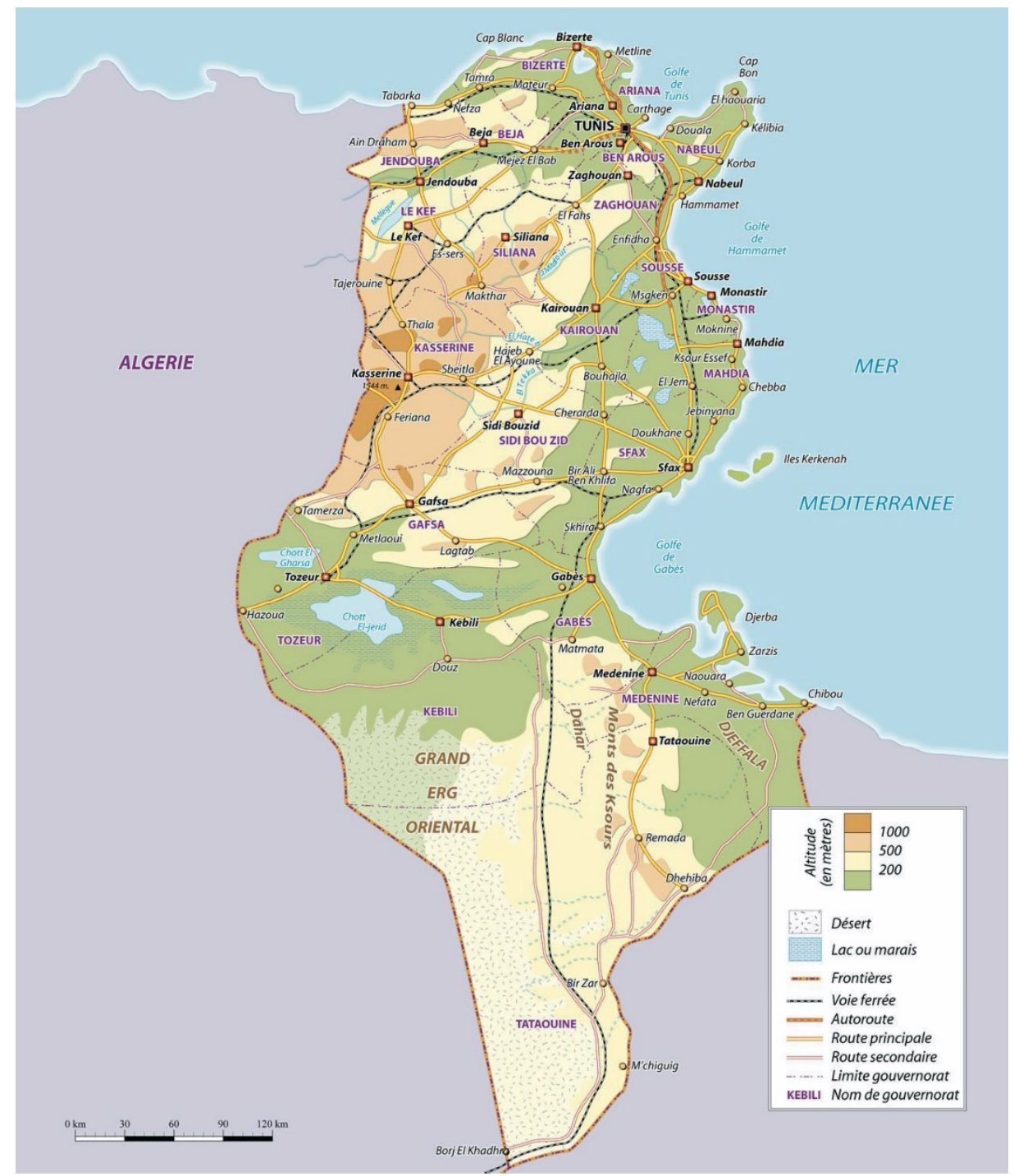

Figure 3: Map of Tunisia. Source: $\underline{\text { Vidiani }}$

For half a century, phosphoric acid and chemical fertilizer production plants have been dumping between 6,000 and 13,000 tons of phosphogypsum sludge every day on shores and at sea (Bielak 2016), wreaking havoc in the marine environment: the disappearance of Posidonia meadows from sea beds below 10 meters for instance, has brought about a stark decline in fish stocks that deeply affected local fishing communities. Although Tunisian health authorities carefully avoid large-scale medical enquiries in the

${ }^{19}$ According to calculations by Sghaier (2010: 28) the ratio between the volume of exploited groundwater and the naturally available resources reaches $117 \%$ nationally.

${ }^{20}$ According to hydrological data of the DGAT (2011: 5), a total of 2,373 wells allow tapping 20 million cubic meters into the both tables whose resources are estimated at $13.9 \mathrm{~m}$ cubic meters (the difference is made possible thanks to infiltration from rainwater or from deep water table from a geological fault). 
Gabes region, ${ }^{21}$ sludge and fumes also induce various respiratory disorders and diseases of the immune system and have caused several deaths among workers but also among children living in the vicinity of the chemical plants (Szakal 2016). ${ }^{22}$ Considering these losses in plant diversity, fish stocks and human lives, scientists from the Institut National Scientifique et Technique d'Océanographie et de Pêche coined the expression "urban genocide" to describe the environmental and health consequences of phosphate transformation in Gabes (Rahali 2013). The Groupe Chimique Tunisien, after recognizing its responsibility for the ecological consequences of illegal dumping of phosphogypsum sludge in 2013, subsequently withdrew to avoid the payment of compensation and, to date, still has not paid compensation for the pollution it generated in the Gulf of Gabes (Chennaoui 2017). This is despite generating daily profits of up to 11 million dinars (US\$4.47m) when operating at full capacity.

Such blatant injustice led to the formation of a vivid environmental activist scene in Gabes before the "Jasmin Revolution." A total of 23 registered civil associations are still working to raise environmental awareness. Extensive graffiti with inscriptions such as "Stop the pollution" are an integral part of the urban landscape of Gabes. Non-violent protest actions targeted at transport routes are frequently organized, together with public concerts featuring local artists specialized in anti-pollution rap and hip-hop (Elaïba 2013). Social networks are used to release documents, statements, pictures, videos and other evidence on the effects of pollution: particularly active in this regard are the Twitter group "\#Gabes pollution"23 and the association "SOS Environnement Gabes" which has a Facebook Group ${ }^{24}$ and a YouTube Channel. ${ }^{25}$

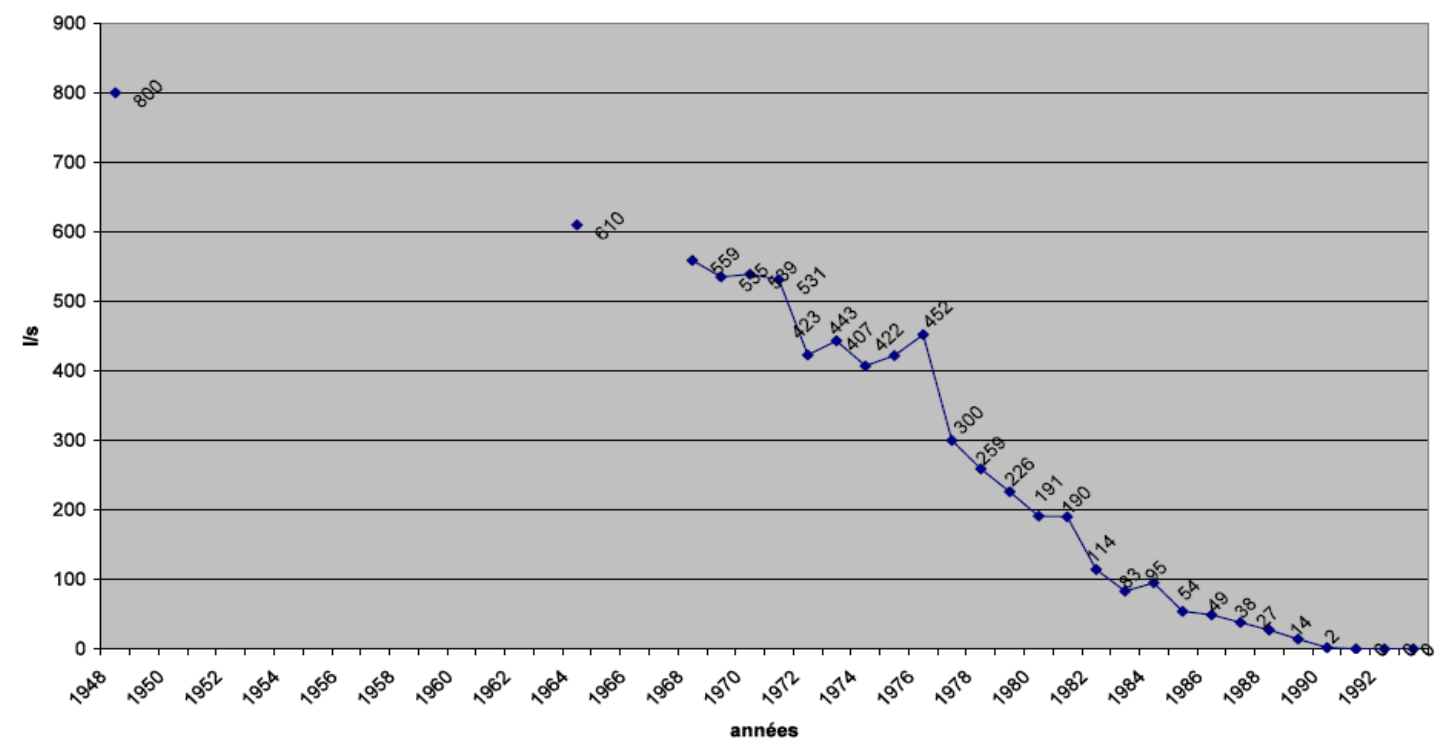

Figure 4: Evolution of the flow rate of springs in the Gabes oasis between 1948 and 1992. Source: Direction Régionale de l'Environnement, quoted in Veyrac-Ben Ahmed and Abdedaiem (2011: 2).

\footnotetext{
${ }^{21}$ In one of the few small-scale studies available and conducted with the support of Amnesty International, it was found that, out of a sample of 662 individuals, $272(40 \%)$ suffered from respiratory diseases and 41 (6\%) from skeletal fluorosis, a rare pathology altering bone structure. (Boukhayatia 2016). In the district of Chott Essalam, located in the immediate vicinity of the GCT factory, the prevalence of lung cancer is estimated at $10 \%$ and kidney cancer at $12 \%$ (Hyatt 2013).

22 In May 2013, two children, Arwa and Dhia Al- Cherif (a brother and a sister), died of an infectious disease of the liver (hepatitis A) which, although the family of the victims never received the children's medical files, was most likely caused by exposure to high levels of industrial pollution. These deaths sparked a violent environmental protest in Chott Esselam that was met by the government with tear gas and police batons (Al Jazeera 2013).

${ }^{23}$ https://twitter.com/search?q=\%23Gabes\%20pollution\&src=typd

${ }^{24}$ https://www.facebook.com/sos.environnement.gabes/

25 https://www.youtube.com/user/guabesna/
} 
Selected excerpts from Gabès Labess (2014)

In the film, after describing farming practices within the oasis, a basic diagnosis is formed (23:1524:57 - Film Clip 1): the oasis is in a state of "total disruption" and "has lost its balance" due to the lack of water. With the creation of the industrial area of Gabes in the 1970s, the water that used to irrigate the oasis naturally was suddenly diverted for industrial purposes, and mainly to clean phosphates coming from the Gafsa region - within weeks, natural water sources started declining and drying up. As explained by an interviewee in the film, "The oasis used to get about 720L/sec of free, natural water. Now we get about 150L/sec only by pumping for which people have to pay out of their own pockets." This resulted in an exodus, as impoverished farmer families left the oasis.

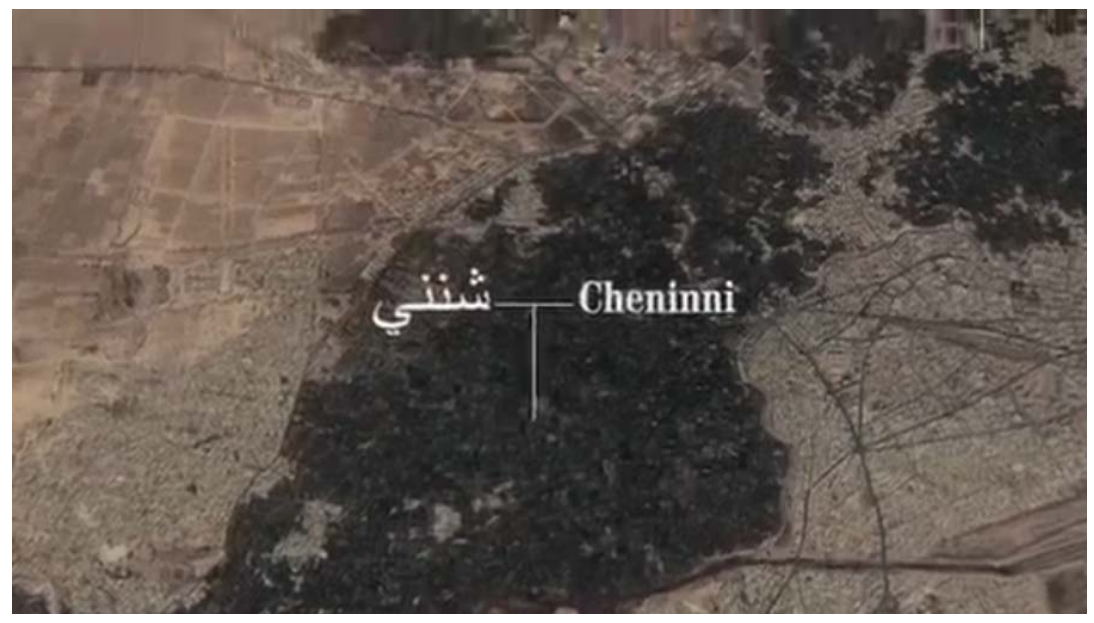

Film Clip 1: Ayeb, H. 2014. Gabès labess - tout va bien à Gabès. 5/5 productions, Les Productions de l'Amaru. 47 min. Reproduced with permission of the copyright owner. Click image to view.

Three short sequences then describe the effects of the industrial complex on selected human activities in surrounding cities, to show the costs of this mode of development. The first sequence deals with marine pollution and the effect on local fishing communities in Ghannouch (25:00-27:40). Recalling the abundance of fish (sea bream, striped sea bream, red mullet) an older fisherman complains that surface fish have now virtually disappeared, most likely due to phosphogypsum discharges. He also explains how, following extension work in the harbor to promote exports, large quantities of poisonous acids were released. For weeks, tons of dead fish and countless bird and turtle carcasses were carried ashore by brown waves.

The second sequence deals with poverty and environmental injustices in the face of air and water pollution (27:50-32:00). With population growth and the need for additional arable land, 150 poor families started occupying and farming state lands in the city of Ghannouch right next to the industrial complex. With humor, they named this area Falloujah after the Iraqi city "because it's a messed up area." Well water is too polluted to drink but is nonetheless used for irrigation, inevitably contaminating vegetables. Ironically, the soil is so poor that farming is only possible with the help of chemical, phosphate-based fertilizers of the kind that are fabricated in the nearby complex.

The third sequence displays a conversation with an elderly traditional farmer endowed with a pronounced political awareness (38:40-43:42). Taking fruit trees as an ideal typical example of modern farming practices, he explains how "the future of farming is with the capitalists." Large land owners specialized on irrigation-intensive crops grown for export have drilled beyond reason, "turning the ground into a molehill" with the estimated effect that water resources will be exhausted within 20 to 30 years, despite all the rhetorical emphasis on sustainability by foreign and national investors. Although public authorities are supposed to regulate and control drilling permits, they are also responsible for accompanying restructuring and modernizing the economy - not to mention that they often turn a blind eye in exchange 
for backhanders. The old man ends up his intervention by making an implicit connection with class struggle. On the one hand, wealthy owners with large properties have virtually unhindered access to credit and can therefore invest in mechanization and irrigation works, as well as specialize in higher-yielding seeds for which there is a strong demand on international markets. On the other hand, small producers with more conservation-friendly practices and specializing in traditional crops for local demand are denied the means to invest, and thus condemned to poverty or exile, thereby joining the ranks of the (sub-)urban proletariat.

\section{Gafsa: birth of a revolution}

In a mere five weeks in December 2010 and January 2011, President Ben Ali - who had been holding office for 21 years - was ousted from power by a popular uprising started in the small town of Sidi Bouzid, almost 300 kilometers away from the capital city of Tunis. ${ }^{26}$ These spectacular events took the world by surprise, as most observers and experts thought it unlikely that a broad social movement could ever prosper in a country with a fiercely autocratic regime, a particularly ruthless secret police and allegedly sound macroeconomic fundamentals. ${ }^{27}$ In that, international observers and IMF experts alike were showing crass ignorance of the contemporary social history in Tunisia which is traversed by a multiplicity of local tensions especially around environmental issues and access to (public service) employment in the less developed interior regions.

Just about three years before the "Jasmine Revolution", a labor strike in the phosphate-producing town of Redeyef initiated a six-month long, large-scale protest and civil disobedience movement. The story of this movement and of its brutal repression is narrated by director Sami Tlili in the 2012 documentary film Cursed be the Phosphate! This film has many merits, one of which is certainly to historicize the "Jasmine Revolution" and show that it did not come out of the blue but rather as an episode in a long series of social and environmental micro-struggles fought by workers mostly without centralized, top-down union control. It also shows the ambivalent relationship of peripheral regions, a mixture of pride and bitterness, towards a revolution that they started but that was subsequently "confiscated by Tunis". From our perspective in this article however, the main virtues of this documentary film are twofold. On the analytical

\footnotetext{
${ }^{26}$ Incidentally, the governorate of Sidi Bouzid is confronted with similar patterns of confiscation that possibly triggered the "Jasmine Revolution", so that the 2010/11 social movement would undoubtedly deserve being analyzed with the conceptual toolbox of political ecology. Located over the country's largest groundwater table and endowed with fertile farmlands, the governorate of Sidi Bouzid is Tunisia's most valuable agricultural region. It has $18 \%$ of national vegetable production, $11 \%$ of milk production, $14 \%$ of the olives produced, $13 \%$ of almonds and $20 \%$ of pistachios. In addition it produces $10 \%$ of Tunisia's meat and has $6 \%$ of the land dedicated to organic farming (source: http://www.investintunisia.tn). Despite its flourishing agricultural sector, Sidi Bouzid is one of Tunisia's poorest governorates - together with Kasserine it has the highest rates of unemployment and unmarried people in the country (Som-I 2017). In Sidi Bouzid as in Gafsa, this is explained by a combination of factors ranging from increased mechanization, low levels of public and private investment that could help finance critical infrastructure, and (with the exception of tomato drying and harissa) an over-specialization in raw production while the revenues created during processing are confiscated by companies located in Sfax or Sousse that are better equipped for the national distribution and international export of food products. The agricultural sector, which already employs around $50 \%$ of the local workforce, is thus saturated - a trend that the ongoing "rationalization" (shift from labor-intensive, small-scale, family farming towards larger, highly mechanized agricultural units) fueled by foreign direct investments and conducted with the support of various programs sponsored by international donors, only deepens. Furthermore, the long-term sustainability of the agricultural sector is threatened by global environmental and political factors. These include climate change, with warming expected to lead to a 7\% decrease in local rainfall and a local temperature rise of 1.1 degree by 2030; and water resources are used at a rate faster than they can be replenished. Tunisia's position in global trade networks means the country has to gradually eliminate its agricultural subsidies and tariff barriers, which is likely to increase domestic production costs and to thus to negatively affect employment due to the stagnating or falling prices of food products on the international market (GIZ 2014:15). Faced with such grim prospects, local youth are left with two options: either stay in Sidi Bouzid and scrape a living by selling leftovers of the agricultural sector in the grey economy (here it is worth remembering that Mohammed Bouazizi, the street vendor who is said to have sparked the Arab Spring, immolated himself after the police allegedly confiscated his illegal fruit and vegetable stall); or migrate. Over 60,000 young people left between 1994 and 2009, which was dramatic for a town with a current population of less than 50,000 (GIZ 2014: 12). In recent times, a third and even more dramatic option has emerged: join ranks with terror organizations such as ISIS or Al-Nosra, which have been heavily recruiting in cities such as Kasserine, Sidi Bouzid or Remada (Gaveriaux 2016; Trofimov 2016; Ratka and Roux 2016).

${ }^{27}$ In late 2008, the IMF praised the country's "growth acceleration and macroeconomic stability" and emphasized that its "pragmatic approach to structural reforms have produced significant gains." See "IMF Managing Director Dominique Strauss-Kahn's statement at the conclusion of his visit to Tunisia", Press Release No. 08/291, November 18 2008.
} 
side, it brilliantly visualizes the systemic political-economic forces within which social-environmental inequalities are embedded, showing that environmental problems such as pollution and social problems such as poverty or high unemployment are not only intertwined but also wrapped within a broader material context that explains their occurrence and permanence. On the more prescriptive side, Tlili's film also illustrates that workers and local populations are well aware of this interconnection and demand holistic solutions that involve a more radical application of democratic ideals: safer working conditions, less precarious short-term contracts and more social security for workers and their relatives; a ban on the most polluting exploitation practices for both environmental and health reasons; a more balanced wealth-sharing mechanism between workers and owners; more transparency on the conditions of access to the comparatively lucrative and safe positions in the public sector; and a greater degree of direct participation in local decision-making, particularly in issues with social and environmental consequences.

\section{Phosphate extraction in Gafsa}

Located in the hinterland 300 kilometers west of Sfax and lacking modern transport and communications infrastructure (six hours train from Tunis!), the governorate of Gafsa did not benefit from the rapid growth in tourism-related services that has taken place in pockets of the country around the capital city and in coastal regions. Due to the arid climate, agriculture (mostly fruit trees) requires costly irrigation work and is thus hardly a profitable economic activity. For these reasons, unemployment reaches $30 \%$ and leaves large fractions of the youth without social protection (Gantin and Seddik 2008). Yet, Gafsa lies at the heart of one of the world's largest phosphate mining regions, giving rise to a mono-industrial development model in which the all-powerful CPG (Compagnie des phosphates de Gafsa, the Gafsa Phosphate Company, a public monopoly) is virtually the only employer in the region. Until the 1970s, the CPG was providing a wide range of public services to its 15,000 employees and to their families (childcare, schooling, hospitals, public transport, football clubs but also water, electricity and banking services). With the neoliberal turn in the 1980s, a number of modernization plans conducted under the auspices of the World Bank brought the workforce down to around 5,000 workers. The two-thirds cut in the workforce was achieved mostly at the expense of youth, by means of a voluntary retirement program combined with a freeze on new hiring. The few jobs available became intensely coveted and an institutionalized system of nepotism and corruption prospered with the participation of local economic, political and union oligarchs (Allal 2009: 174-179).

In addition to releasing a distinctive sulphur odor reminiscent of rotten eggs, phosphate mining is a particularly pollution-intensive activity: to produce 8 tons of phosphate, 10 million cubic meters of fresh groundwater must be pumped from fossil aquifers, rapidly depleting water available for other activities (Dahmani 2012). ${ }^{28}$ In the extraction process, wash or rinse waters containing elevated levels of highly toxic heavy metals (such as cadmium, lead, nickel, copper, chromium and uranium) are then dumped in the wild, affecting plants and marine life but also animals and humans via breathing and ingestion of contaminated food products (Economist 2014). Among the most frequent conditions associated with these heavy metals are pneumonitis (inflammation of the lung alveoli) caused by exposure to cadmium; miscarriages, fetus malformations, premature deliveries as well as various growth disorders for children, and nephropathy (colic-like abdominal pain) caused by lead poisoning. There are also multiple cancers due to exposure to weekly radioactive elements such as uranium and radium contained in phosphogypsum. Dust inhalation also causes silicosis, a frequent lung disease characterized by shortness of breath, cough, fatigue and weight loss in mild cases and it is potentially lethal in more severe cases.

In a nutshell, the Gafsa Governorate, which is the heart of the phosphate industry, suffers from all manner of economic, social and environmental harms linked with extraction. But it is deprived of any access to its benefits, which are either channeled towards national trade hubs or locally confiscated by corrupt elites. Although the phosphate industry represents around $20 \%$ of the national budget, $4 \%$ of the GDP and $10 \%$ of foreign exchange proceeds, it is estimated that less than $10 \%$ of the revenues remain in the Gafsa Governorate (Steinich 2015). With the restructuring of production, the state failed to create a more diversified economy while international financial constraints on the budget of the Tunisian state hindered

${ }^{28}$ In 2010, the CPG extracted 8 million tons phosphate. This number has dwindled after the revolution - current production is estimated at around 3.5 million tons (U.S. Geological Survey, Mineral commodity summaries, January 2017, available at: https://minerals.usgs.gov/minerals/pubs/commodity/phosphate_rock/mcs-2017-phosp.pdf) 
job creation in the public sector. ${ }^{29}$ The tragic absurdity of this situation has been vividly expressed by journalist Lakhdar Souid (cited in Dahmani 2012): "since 115 years, the CPG is like a cash cow, whose dung stays in Gafsa and whose milk is sold elsewhere, leaving its calves starving."

In January 2008, unemployed youth from the small town of Redeyef, many of whom were graduates, started a peaceful protest movement after the publication of the results of the highly competitive entrance exam for positions in the CPG, which had patently been rigged with the tacit consent (in some cases with the active participation) of the regional office of the UGTT, Tunisia's powerful worker's union. ${ }^{30}$ In a region with a strong tradition of political activism and rebellion, the movement soon received the support of local teacher unionists such as Béchir Laabidi, Adnene Hajji and Adel Jayar, who also opened their schools for organizing covert meetings. ${ }^{31}$ The first skirmishes broke out after the police started arbitrarily detaining participants in the movement. This gave central authorities in Tunis the justification they needed to send an astonishing 30,000 policemen to crush the rebellion in Redeyef (a town of 25,000 inhabitants). Predictably, repression was ruthless: a curfew with police combing buildings, property damage, insults, and the use of batons, tear gas, dogs, water cannons and live ammunition to disperse demonstrations. There were at least three deaths (Chouikha and Gobe 2009). ${ }^{32}$ According to Amnesty International (2009), over 300 people were arbitrary detained, more than 200 participants in the movement were prosecuted (many of them were condemned to heavy prison sentences) - in addition, a number of detainees were "kicked, beaten all over the body and on the soles of the feet, burned with cigarettes on sensitive parts of the body, suspended in contorted position, raped by the insertion of objects in the anus, or threatened with rape or sexual abuse of female relatives." The policemen responsible for these crimes were never brought to court. Despite its length and intensity, this daring and tragic protest movement has still not been recognized as "the first uprising of the Arab Spring" (Gall 2014).

\section{Selected excerpt from Cursed be the phosphate! (2012)}

The sequence chosen (00:59:45-01:02:49 - Film Clip 2) features interviews that are so powerful and cogent that they were quite likely scripted, interspersed by alternately lamenting and accusatory voice-over poetry composed by Sami Tlili. The interviewee Moudhaffer is the son of a local unionist involved in the protest movement. At this stage of the film, the viewer has already been brought to a point where she is disposed to giving sympathetic consideration to Moudhaffer's testimony thanks to an earlier sequence in which the young and handsome man declaims a poem written by his father in prison while forced to listen to his son (Moudhaffer himself) being tortured in the neighboring detention room. ${ }^{33}$

In this very dense sequence, three major issues are tackled. The first theme is the inertia of hegemonic structures beyond regime change, from the perspective of the subaltern or of the periphery. It is suggested by means of a voice-over commentary that insists on the continuity between the colonial period and independence:

The beret-wearing foreigner went away and was replaced by the turban-wearing foreigner but the same evil remained. And we saw neither riches nor well-being, only the ever-watching baton. What is the link between the beret and the turban? They share neither nationality nor religion in common. What is the link between the beret and the turban? It's the dough, the dough, the dough.

\footnotetext{
${ }^{29}$ Such constraints are primarily exerted by foreign donors and the International Monetary Fund. To take a recent example, Finance Minister Lamia Zribi announced in February 2017 that Tunisia was to sell stakes in three state-owned banks and cut up to 10,000 public sector jobs as part of an IMF "reform package" in order to receive the second tranche of a US\$350 million loan (Amara 2017).

30 The Union Générale Tunisienne du Travail [Tunisian General Labor Union] is Tunisia's oldest and most powerful national trade union, with a membership of over 500,000 in 2010 (International Trade Union Confederation 2010).

${ }^{31}$ The Gafsa region was for instance the epicenter of the five-week long bread riots in 1983/1984.

${ }^{32}$ Hafnaoui Maghzaoui, Abdelkhalek Amaidi and Hichem Alaimi.

${ }^{33}$ Moudhaffer is also involved in another scene designed to create sympathy and a form of emotional attachment (1:10:47-1:11:08). Leaving Paris to visit his family, Moudhaffer asks a taxi driver to bring him to the police station in Redeyef (where he was detained and tortured), because he wants to chat with policemen and ask them for a lighter. Moudhaffer is informed by the taxi driver that there is no more police station and that policemen have fled in the mountains. "Is this anarchy then?" asks Moudhaffer - "no, self-management / self-government (autogestion)" answers the taxi driver with a mischievous smile.
} 


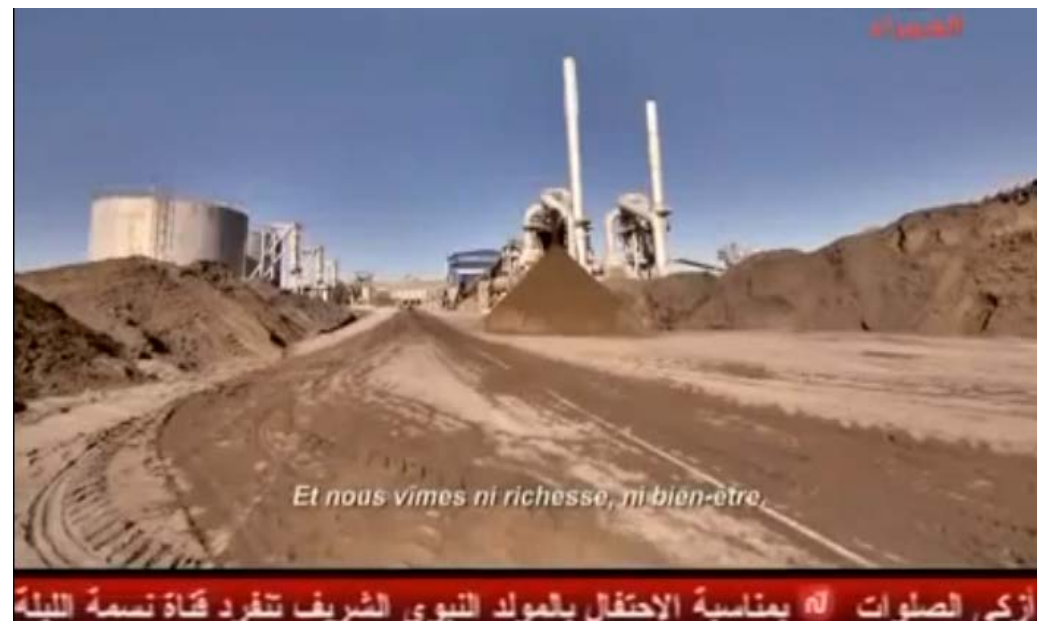

Film Clip 2: Tlili, S. 2012. Cursed be the Phosphate. Nomadis Images / Cinetelefilms. 78 min. Reproduced with permission of the copyright owner. Click image to view.

Already present in the first voice-over comment, the theme of exploitation, confiscation and accumulation by dispossession is further explicated by Moudhaffer in an interview on a clean Parisian bridge:

Cursed be that phosphate that I extract and that only enriches others... we never benefited from this wealth that lies under our homes... my teeth are all yellow because of phosphate, ${ }^{34}$ it is something that has taken root in me. I cannot get rid of the phosphate in me. When the phosphate-processing plant does not emit its fumes in our homes, it is the dynamite used in the mines that makes our walls and windows tremble.

The third fragment of this sequence evokes youth disillusionment in the face of political authoritarianism and all too familiar scenes of boats full of migrants attempting to cross the Mediterranean. Using the same powerful voice-over technique, Sami Tlili exposes the viewer to a bitter vituperation of those who "condemn us to depart or to dream of departure towards European cities and Italian beaches. We have emigrated bodies and souls and left him alone hunting cockroaches in the country of infinite safety and security."

\section{Jemna: resistance meets the state}

In Tunisia, resistance against extractive industries (whether phosphate, gas or oil) often takes the form of largely nonviolent strikes and demonstrations - with sit-ins and physical occupation of symbolic buildings - and unemployed youth have brought production to a halt by means of rail/road blockades. The demands articulated by these protest movements often combine social and environmental justice: job creation, profit-sharing, local investment and development plans, a cleaner environment, and safer working conditions. In many ways, this amounts to defensive tactics where 'dispossessed subalterns' hold on to their valuable resources and demand fairer compensation before letting go. ${ }^{35}$ This tactic carries risks, however as hegemonic power structures frequently react by cracking down with a brutality that their self-entrusted

\footnotetext{
${ }^{34}$ Exposure to fluoride, a common byproduct of phosphate extraction, results in a condition known as dental fluorosis, characterized by tooth discoloration and, in severe cases, physical damage to the teeth.

${ }^{35}$ A recent example of these tactics is the conflict over a large gas concession in Chergui on the island of Kerkennah (also in the Gulf of Gabes) in which British oil and gas company Petrofac was forced into a compromise by demonstrations and blockades by unemployed youth. For an overview of the movement, see Hamouchene (2016) and Chomiak (2016).
} 
monopoly on the legitimate use of violence supposedly justifies. Such behavior can be seen in Tunisia, where the newly democratic state itself reproduces patterns of domination inherited from colonial times. ${ }^{36}$

Making demands for a fairer cost- and profit-sharing regime do not constitute a fundamental break with extractivist developmental logics - even if these demands are met. A more radical critique of these logics involves renouncing "visions of NGOs that posit the regulation of the degradation of nature apart from the implications of capital as a social relation-in other words, without recognizing the problem of private appropriation of public goods" (López and Vérdiz 2015: 160). In a Gramscian sense, the formulation of a genuinely alternative, counter-hegemonic project thus requires of social-environmental protest movements, first and foremost that they be able to reject the set of beliefs and values defined and imposed through the state by a historically dominant social group to legitimize particular modes and relationships of production. Yet here again, any attempt to disrupt the hierarchy of norms that legitimizes the roles and positions of various social groups will be met with fierce opposition from the state, independently from its democratic or autocratic character, as illustrated by the experience of the Jemna community palm grove.

In January 2011, two days before Ben Ali fled his country, youth expelled two corrupt managers with ties to the old regime from a palm grove famous for the quality of its deglet nour dates in the small oasis town of Jemna in the governorate of Kebili, on the margins of the Chott el Djerid salt lake (in the south-west of the country). As in neighboring cities such as Tozeur, there were initial talks about dividing the land and giving it to local families under a private property regime. Yet, the prospect of inequalities between families led to a brief episode of violence that the town elders were able to appease by proposing joint administration under a collective/common property regime (Chennaoui 2015). Since then, production of dates has doubled, employment has risen from 20 to 130 workers mostly on stable contracts, and under the regime of collective administration the palm grove was able to invest around 600,000 euros (US\$717,000) in local development projects, ${ }^{37}$ compared with the 50,000 euro (US\$60,000) rental costs that had been collected by the state in the nine years during which the two crooked managers controlled the oasis (Hamouchene 2017). Yet, these spectacular results were achieved in a context of tension with the state, which refused to acknowledge the legitimacy of the "association for the safeguard of the Jemna oasis" (the democratic decision-making body on issues of collective management) on the grounds that it illegally grabbed federal lands (that is: lands the newly independent Tunisian state claimed for itself shortly after French colonialists were forced out). As a result, the state froze the accounts of the association after the harvest to prevent it being sold. The inhabitants of Jemna (including many families that had been working on the site for generations even since before colonial times) were then left with no other choice than to accept the status of a state-sanctioned cooperative arrangement, a decision they deeply resented as they felt it ignored their historical rights. It forced them to regularly ask the permission of the state to pursue their activities in the framework of a public system of bidding that has a requirement for free and fair competition - which cannot give them long term assurances. The fact that the Tunisian state perpetuates mechanisms of social and economic domination even after its independence from colonial powers and its democratic "revolution", is a corroboration of Brand's work (2011: 152) regarding the difficulty faced by progressive governments in Latin America to change the structures of the state after their election:

The social forces of these countries must articulate their interests, values and projects within the same old capitalist and post-colonial state and must act using a structure that forces them to submit to its rules... which hampers change. [my translation]

\footnotetext{
${ }^{36}$ In May 2017, Tunisian President Beji Caid Essebsi ordered the army to protect phosphate mines and gas fields operated by foreign companies such as ENI (Italy), OMV (Austria) and Serinus Energy (Canada), after 1,000 unemployed demonstrators in the Tataouine province (Tunisia's Southern Sahara) threatened to blockade roads. Essebsi's Energy Minister insisted that "cutting off routes and halting energy production is a crime. It will not be tolerated anymore because it is destroying the economy" (Souissi 2017).

${ }^{37}$ Among other things: the building of an indoor market, the renovation of a local school, investments in cultural and sports infrastructure, financial support to various cultural, religious and health institutions supporting mentally ill people, but also the IT equipment for the public library and the police station! See Etahri (2016).
} 
Echoing Badiou's concept of "subtraction" (2007), this may be taken as an indication that genuinely emancipatory politics is only possible not against the state precisely, but rather at a distance from the state, in interstitial spaces. ${ }^{38}$

\section{Conclusion}

Whether in Gabes or Gafsa, the confiscatory workings of the phosphate industry in Tunisia can fittingly be described and understood by reference to the concept of "extractivism" forged by LatinAmerican scholars (Acosta 2009; Gudynas 2011; Svampa 2011). Fueled by a voraciously rising global demand for chemical fertilizers, transnational capital - foreign investors, international financial institutions and multinational companies associated with national elites and central power structures - uses cheap labor in the Tunisian South and Interior to extract and transform phosphorous minerals in resource-endowed regions. This creates local dependencies because it is a mono-activity. The much-coveted commodity is then exported internationally to be utilized for agricultural purposes or further transformed into higher value products while social, environmental, ecological and health "externalities" remain at the local level. In addition, the value-added is captured by trade centers inserted in global networks of exchange and commerce rather than being locally distributed - when it is not simply confiscated by political and economic elites in Tunis.

Historically, this system has been kept stable thanks to a mixture of violence and constraint (colonialism, political authoritarianism, restrictions on social rights, brutal police repression) as well as by consent that is bought (in particularly through high levels of employment and various benefits awarded to employees and their families in state monopolies). These decade-old arrangements were shattered by the "neoliberal turn" (Duménil and Lévy 2004; Harvey 2005): the liberalization of world trade brought about an intensification of international competition that forced the Tunisian phosphate industry to downsize its workforce. In addition, the state - encouraged by international "donors" through the mechanism of conditionality - became party to a number of liberal agreements to facilitate investment and free trade, as a result of which "the demands of the global market, such as extractivism, are written into state structures and public policies" (Brand 2011: 156 - my translation), thus rendering the emergence of (peaceful) political alternatives increasingly difficult. Even the spectacular and violent events that became known as the "Jasmine Revolution" did not fundamentally affect relationships of production in Tunisia: as shown by the experience of Jemna but also by the commitment of the Islamist governments of Hamadi Jebeli and Ali Larayedh to honor Ben Ali's odious debt, or by the decision of secular President Essebsi to send the army against demonstrators in the Tunisian South to prevent a blockade of production sites controlled by foreign investors. The newly democratic Tunisian state tends to reproduce domination patterns inherited from the previous regime and the colonial period.

In addition to providing new empirical insights on Tunisian regions for which there is little published material in English language to date, this article is further evidence that theories of social change must not be restricted to the macro-level of political institutions but must also consider the micro-level of social practices and relationships, particularly relationships of production. Amidst the welter of foreign policy analyses on the "Jasmin Revolution", this study of phosphate extraction and transformation in the Tunisian South and Interior leads to a bleak conclusion: in Gafsa and Gabes, the revolution still has to take place.

\section{References}

Abdedaiem, S. and B. Veyrac-ben Ahmed. 2015. Le paradoxe des oasis du sud tunisien: rénovation ou mort d'un concept? In A. Marshall, E. Lavie, J.-L. Chaléard, M. Fort and J. Lombard (eds.). Actes du colloque international "Les oasis dans la mondialisation: ruptures et continuités". Paris, December 16-17, 2013. Pp. 21-27.

Abderrazak, S.B. 2016. l'économat de Redeyef: puissance poétique, utopie politique. Nawaat, May $10^{\text {th }}$

\footnotetext{
${ }^{38}$ One such space is the économat in Redeyef. Amidst post-apocalyptic phosphate landscapes, a handful of young activists - mostly young men caught in a cycle of unemployment and short-term precarious contracts - reclaimed an old building formerly in the hands of the phosphate industry and collectively restored it over three months, using recovered materials and YouTube tutorials (Ben Abderrazak 2016). They also organize movie shows and public discussions, photo exhibitions and theater plays and public readings of Arabic poetry and rap concerts, turning the place into a self-managed cultural center with plans to open an alternative café, a community library and a small movie theater (Thibaudat 2016).
} 
Acosta, A. 2009. La maldición de la abundancia. Quito: Ediciones Abya-Yala.

Allal, A. 2009. Ici si ça ne «bouge » pas, ça n'avance pas! In Catusse, M, B. Destremau and E. Verdier (eds.), L'État face aux débordements du social au Maghreb. Paris: Karthala. Pp 73-186.

Amara, T. 2017. Tunisia to accelerate reforms as IMF freezes loan. Reuters, February $27^{\text {th }}$.

Amnesty International. 2009. Tunisia: behind Tunisia's 'economic miracle': inequality and criminalization of protest Nawaat, June $18^{\text {th }}$

Ayeb, H. 2016. L'écologie en Tunisie entre environnementalisme de mode postrévolutionnaire et urgences environnementales et sociales. $\underline{\text { Huff Post Maghreb }}$, February $24^{\text {th }}$

Ayeb, H. 2015. Pour plus de justices sociales et environnementales, changeons de modèle économique. Tunisia in Red, August $15^{\text {th }}$

Ayeb, H. 2012. Compétition sur les ressources hydrauliques et marginalisation sociale, à qui profite la disparition des canaux? In C. Aspe (ed.). De l'eau agricole à l'eau environnementale: résistance et adaptation aux nouveaux enjeux de partage de l'eau en Méditerranée. Paris: Quae. Pp. 143-155.

Ayeb, H. 2014. Gabès labess - tout va bien à Gabès. 5/5 productions, Les Productions de l'Amaru. 47 min.

Badiou, A. 2007. Destruction, negation, subtraction - on Pier Pasolini. Graduate Seminar at the Art Center, College of Design in Pasadena, February $6^{\text {th }}$

Bensaïd, D. 1993. Le tourment de la matière: Marx, productivisme et écologie. Working Paper 28. International Institute for Research and Education

Bielak, H. 2016. Tunisie: le poison de Gabès, Amnesty International France, November $9^{\text {th }}$

Blaikie, P.M and H.C. Brookfield 1987. Land degradation and society. London: Methuen

Blaikie, P.M. 1985. The political economy of soil erosion in developing countries. London and New York: Longman

Boukhayatia, R. 2016. Tunisie: zoom sur "le poison de Gabès" ou les récits d'une ville qui tue ses habitants. Huff Post Maghreb Tunisia, November $11^{\text {th }}$

Brand, U. 2011. El papel del estado y de las políticas públicas en los procesos de transformación. In M. Lang and D. Mokrani (eds.), Más allá del desarrollo. Quito: Fundación Rosa Luxemburgo/Abya Yala. Pp. 145-158.

Carpentier, I. and A. Gana. 2015. Les oasis de Tozeur et Chenini Gabès: diversité et durabilité des formes de valorisation à l'ère de la mondialisation et des crises du développement. In A. Marshall, E. Lavie, J.-L. Chaléard, M. Fort and J. Lombard (eds.). Actes du colloque international "Les oasis dans la mondialisation: ruptures et continuités". Paris, December 16-17, 2013. Pp. 105-112.

Chennaoui, H. 2017. Gabès-Reportage: après 45 ans de pollution, les revendications se radicalisent. Nawaat, April 26 $6^{\text {th }}$

Chennaoui, H. 2015. La ferme de la STIL à Jemna: quand l'intérêt collectif devance le gain personnel. Nawaat, July $11^{\text {th }}$

Chomiak, L. 2016. The revolution in Tunisia continues. Middle East Institute, September $22^{\text {nd }}$

Chouikha, L. and E. Gobe. 2009. La Tunisie entre la "révolte du bassin minier de Gafsa" et l'échéance électorale de 2009. In L'Année du Maghreb. Paris: CNRS Editions. Pp. 387-420.

Collectif. 2012. Altergouvernement - 18 ministres-citoyens pour une réelle alternative. Paris: Le Muscadier.

Cordell, D. 2008. The story of phosphorus: missing global governance of a critical resource. Paper prepared for SENSE Earth Systems Governance, Amsterdam, August $24^{\text {th }}-31^{\text {st }}$

Dahmani, F. 2012. Gafsa, éternelle poudrière. Jeune Afrique January $29^{\text {th }}$

DGAT [Direction Générale de l'Aménagement du Territoire]. 2011. Atlas du Gouvernorat de Gabès. Ministère du Transport et de l'Équipement.

Duménil Gé and D. Lévy. 2004. Capital resurgent: roots of the neoliberal revolution. Cambridge, MA: Harvard University Press.

Economist, The. 2014. Pollution in Tunisia: dirty business. December $14^{\text {th }}$

Elaïba, I. 2013. Tunisie: État des lieux de la pollution causée par le Groupe Chimique Tunisien à Gabès. HuffPost Maghreb, July $17^{\text {th }}$

Etahri, T. 2016. La commune de Jemna. Intervention du président de l'association de Jemna, lors de la réunion publique de soutien du 6 décembre 2016 à Paris. 
Fadhel, I. and Osman, N. 2014. Tunisia embeds climate change in Constitution. Partnership on Transparency in the Paris Agreement.

Gall, C. 2014. Discontent in Tunisia is reflected in the mines. New York Times, May $14^{\text {th }}$

Gantin, K. and O. Seddik. 2008. Révolte du « peuple des mines » en Tunisie. Le Monde diplomatique, July

Gaveriaux, L.-M.. 2016. Kasserine ou la Tunisie abandonnée. Le Monde Diplomatique, January

Gezon, L. and S. Paulson (eds.). 2017. Degrowth, culture and power. Journal of Political Ecology 24: 425666. Special section.

GIZ [Deutsche Gesellschaft für Internationale Zusammenarbeit]. 2014. Plan régional d'environnement et de développement durable (PREDD) du Gouvernorat de Sidi Bouzid. September.

Goldstein, Eric. 2014. Tunisia's legacy of pollution confronts democratic politics. Open Democracy, May $23^{\text {rd }}$

Gorz, A. 2008. Ecologica. Paris: Galilée.

Gorz, A. 1997. Misères du présent, richesse du possible. Paris: Galilée.

Gudynas, E. 2011. El Nuevo extractivismo progresista en America del Sur: tesis sobre un viejo problema bajo nuevas expersiones. In Acosta A., E. Gudynas, F. Houtard, H. Ramírez Soler, J. Martínez-Alier and L. Macas (eds.). Colonialismos del siglo XXI. Negocios extractivos y defensa del territorio en América latina. Barcelona: Icaria Editorial. Pp. 75-92.

Guillermou, Y. 2011. La terre, l'eau et l'arbre. Enjeux fonciers, politiques publiques et stratégies des producteurs ruraux dans les zones arides du Maghreb. In G. Vianey, M. Requier-Desjardins and J.C. Paoli (eds.) Accaparement, action publique, stratégies individuelles et ressources naturelles: regards croisés sur la course aux terres et à l'eau en contextes méditerranéens. Paris: Centre International de Hautes Etudes Agronomiques Méditerranéennes. Pp.199-213.

Hamdène, Z. 2016. Where are poor in Tunisia? Socioeconomica - The Scientific Journal for Theory and Practice of Socio-economic Development 5(9): 109-118.

Hamouchene, H. 2017. Jemna in Tunisia: an inspiring land struggle in North Africa' in: OpenDemocracy, April $13^{\text {th }}$

Hamouchene, H. 2016. Kerkennah: on the frontline of resistance to the fossil fuel industry in Tunisia. OpenDemocracy, June $4^{\text {th }}$

Harpagès, D. and S. Latouche. 2012. Le temps de la décroissance. Lormont: Le Bord de l'eau. Second edition

Harribey, Jean-Marie. 2001. Marxisme écologique ou écologie politique marxienne. In J. Bidet and M. Kouvélakis (eds.) Dictionnaire Marx contemporain. Paris: Presses Universitaires de France. Pp 83200.

Harvey, D. 2005. A brief history of neoliberalism. Oxford: Oxford University Press

Harvey, D. 2004. The 'new' imperialism: accumulation by dispossession. Socialist Register 40: 63-87.

Heckenmüller, M., D. Narita and G. Klepper. 2014. Global availability of phosphorus and its implications for global food supply: an economic overview. Kiel Working Paper No. 1897. Kiel Institute for the World Economy.

Hyatt, J. 2013. In Southern Tunisia, pollution no longer swept under the rug. Inter Press Service News Agency, June $7^{\text {th }}$

International Trade Union Confederation. 2010. List of affiliated organizations, 6th General Council in Vancouver on June $21^{\text {st }}$

Jazeera, Al. 2013. Pollution in Gabes, Tunisia's shore of death June $14^{\text {th }}$

Kempf, H. 2007. Comment les riches détruisent la planète. Paris: Seuil.

Keucheyan, R. 2014. La nature est un champ de bataille. Paris: Zones.

Latouche, S. 2006. Le pari de la décroissance. Paris: Fayard.

Lipietz, A. 1996. La société en sablier. Le partage du travail contre la déchirure sociale. Paris: La Découverte.

López, E. and F. Vértiz. 2015. Extractivism, transnational capital and subaltern struggles in Latin America. Latin American Perspectives 42(5): 152-168.

Löwy, M. 2011. Écosocialisme: l'alternative radicale à la catastrophe écologique capitaliste. Paris: Poche. 
Löwy, Michael (dir.). 2003. Capital contre nature. Paris: Presses Universitaires de France.

Mathias, J.-C. 2009. La politique de Cassandre. Paris: Le Sang de la terre.

Partant, F. 1982. La fin du développement. Paris: Actes Sud.

Pinçon-Charlot, M. and M. Pinçon. 2009. Paris. Quinze promenades sociologiques. Paris: Payot.

Pinçon-Charlot, M. and M. Pinçon. 2007. Les ghettos du Gotha. Comment la bourgeoisie défend ses espaces. Paris: Seuil.

Rahali, F. 2013. Gabès, cité antique de Takapes : une terre maudite? Nawaat, June $5^{\text {th }}$

Ratka, E. and M.-C. Roux. 2016. Dschihad statt demokratie? Tunesiens marginalisierte jugend und der islamistische Terror. In Auslandsinformationen der Konrad-Adenauer-Stiftung 1. Pp. 68-87.

Robbins, P. 2012. Political ecology: a critical introduction. Malden, Mass.: Wiley-Blackwell. Second edition.

Römer, W. 2009. Ansätze für eine effizientere nutzung des phosphors auf der basis experimenteller befunde. Berichte über Landwirtschaft 87(1): 5-30.

Seufert, V., N. Ramankutty and J. Foley. 2012. Comparing the yields of organic and conventional agriculture. Nature 485: 229-232.

Sghaier, M. 2010. Etude de la gouvernance des ressources naturelles dans les oasis. Cas des oasis en Tunisie. Union Internationale pour la Conservation de la Nature / UKAid, December.

Som-I, J.-D. 2017. Tunisia: unemployment has killed me. Journal of Middle Eastern Politics and Policy. May $15^{\text {th }}$

Souissi, Z. 2017. In marginalized south Tunisia, unrest over gas tests government. Reuters, May $15^{\text {th }}$

Steinich, A. 2015. Phosphat-krise in Tunesien. Die ausgeschlossenen von Gafsa. Neue Zürcher Zeitung, July $15^{\text {th }}$

Svampa, M. 2011. Extractivismo neodesarrollista y movimientos sociales: ¿un giro ecoterritorial hacia nuevas alternativas? In M. Lang and D. Mokrani (eds.), Más allá del desarrollo. Quito: Fundación Rosa Luxemburgo/Abya Yala. Pp. 85-218.

Szakal, V. 2016. Report: international mobilization against pollution in Gabes. Nawaat, November $8^{\text {th }}$

Tanuro, D. 2012. L'impossible capitalisme vert. Paris: La Découverte.

Thibaudat, J.-P. 2016. Redeyef, sud tunisien (3/3): la folle journée de l'économat. Médiapart, May $11^{\text {th }}$

Tlili, S. 2012. Cursed be the Phosphate. Nomadis Images / Cinetelefilms. 78 min.

Trofimov, Y. 2016. How Tunisia became a top source of ISIS recruits. Wall Street Journal, February $25^{\text {th }}$

United Nations, Department of Economic and Social Affairs, Population Division. 2015. World population prospects: the 2015 revision, key findings and advance tables. Working Paper No. ESA/P/WP.241.

United Nations, Food and Agriculture Organisation. 2016. World fertilizer trends and outlook to 2019. Summary Report. Rome: FAO.

United Nations, Food and Agriculture Organisation. 2007. Organic agriculture can contribute to fighting hunger - but chemical fertilizers needed to feed the world. Roma: FAO Newsroom, December $10^{\text {th }}$

Veyrac-Ben Ahmed, B. and S. Abdedaiem. 2011. Incidences de la « modernisation » du réseau d'irrigation sur l'écosystème oasien: le cas de l'oasis de Gabès (Sud-est tunisien). Contribution au Colloque « Usages écologiques, économiques et sociaux de l'eau agricole en Méditerranée », Université de Provence.

Watts, M.J. 1983. Silent violence: food, famine and peasantry in northern Nigeria. Berkeley: University of California Press.

Willer, H. and J. Lernoud. 2017. The world of organic agriculture: statistics and emerging trends 2017. Research Institute of Organic Agriculture FiBL / IFOAM Organics International.

World Bank. 2014. The unfinished revolution. Bringing opportunity, good jobs and greater wealth to all Tunisians. Tunisia: Development Policy Review. Report No. 86179-TN. May $24^{\text {th }}$ 